\title{
THE TETON COUNTRY: AN ANTHOLOGY
}

\author{
Robert Righter \\ Department of History \\ Univensity of Wyoming \\ Laramie
}

\section{Introduction}

Jackson Hole, the Teton Range and the Yellowstone Country are perhaps unmatched in alpine beauty. Millions of A mericans yearly draw inspiration and renewal through visiting this diverse region of nature's splendors unsurpassed. Yet the region was among the last to be revealed to the American people. Certainly not because the region is uninteresting. On the contrary, it represents one of the most geologically intriguing and scenically compelling lands within America. No, the region was unknown for more practical reasons. It was hundreds of miles distant from the primary immigrant routes across the nation. No significant mineral strikes provided "instant urbanization." Not even pioneer farmers or cattlemen found the region attractive. Altitude, deep snows, shallow soil, and a short growing combined to discourage farmers. Ranchers did better but struggled during the long winters. Even the timber was classed inferior. Lodgepole Pine trees of marginal commercial worth carpeted the hills. Lumbermen found opportunity further west, amongst the mist and fog-shrouded coastal ranges of the Pacific Slope. In short, aside from scenery and some rather bizarre geothermal activity, there was little attraction to the Greater Yellowstone area, and no reason for settlement.

Therefore, descriptions which one might find of Yosemite in the 1850 s must wait until the 1870 s for the Teton Country. It was in that decade a covey of writings revealed the region to a curious nation, Montanan businessmen, Northern Pacific Railroad officials, and government explorers were responsible.

These early travel accounts are full of the excitement of discovery. Although such men as Nathaniel Langford, Ferdinand V. Hayden, and James Steveson were not easily impressed, they could not surpress superiatives for the Teton Country. No wonder, for well over 100 years the symbiotic, matchless combination of a broad valley, a swift, clear river, exquisite glacial lakes, and precipitous mountains has challenged the descriptive ability of some of A merica's most creative men and women.

However spectacular the Teton Country, in the early years it was not widely known to Americans. Yellowstone, on the other hand, was the object of countless books and articles. Why this disparity in publicity is somewhat speculative. Certainly the fact that Yellowstone was designated in 1872 as a national park increased interest and visitation. Accessibility by rail made northern Yellowstone county much easier to reach. Beyond these reasons I 
believe Yellowstone's popularity may be attributed to its unique thermal activity. No place in the United States, or indeed the world, could tourists view geysers, hot pools and mud pots in such abundance and in such a splendid setting. Mountains, on the other hand, are the attraction of the Teton Country. Mountains are everywhere. Traveling thousands of miles to see mountains, however spectacular, did not occur so readily to the A merican leisure class at the turn of the century.

Therefore, while Yellowstone Park accounts are numerous, descriptions of the Tetons country are more scarce. However, one ought not to assume that they were non-existant. People came to the Teton Country and they wrote about the experience. Some, such as Nathaniel Langford, were part of official exploring parties. Others, such as Theodore Roosevelt, came to hunt. Early on Jackson Hole developed a reputation for fine big game hunting, a reputation which continued throughout this century. The beauty of the country, however, could not be ignored. Increasingly, well-to-do Easterners found the Teton Country an idyllic retreat from the city and summer humidity. The dude ranch business was born. Persons of means and education, such as Catherine and Struthers Burt, established ranches which were more attuned to the needs of guests than cattle. Dude ranches featured a close but comfortable relationship with nature, appealing to an upper class which could afford to travel and spend a month or more in semi-primitive leisure. Some of our best accounts of the early Teton Country come from the "dudes", people who felt the beauty of the country, and could articulate those feelings through the written word.

The Teton Country story, however, is more than one of visitation and description. Unlike Yellowstone, it has a dramatic human history. In Yellowstone, park status preceded any settlement. In the Teton Country the opposite is true. Because people settled in Jackson Hole before the national park was established, a dramatic story unfolded as the forces of private property and public conservation collided in a mighty struggle which continued, in varying degrees of intensity, for 52 years. Few residents of Jackson Hole were immune to the battle. As Olaus and Margaret Murie found out, it was almost impossible not to side with either the National Park Service or, on the other side, the cattlemen and local businessmen. Because this conservation battle was so central to the development of a "Jackson Hole attitude," some essays which are more political than descriptive have been included.

Certainly today it is difficult for the visitor to imagine northern Jackson Hole as any different than it is. However, the outcome was in question for decades, as opposing forces struggled for control of the land. Of course, all factions professed to have the best interests of land and people at heart, but just how much development would take place was, and still is, a central theme in the Teton Country history and collective psyche.

Selecting the most pertinent and interesting essays on such a broad subject as the Teton Country must inevitably force hard dicisions. Should essays be included about the characters of Jackson Hole? I decided no, unless their reputation extended beyond the Hole. Should stories which focus on the town of Jackson be included? Should portions from novels be used? To both these questions I decided in the negative with one exception: That is Owen Wister's 
The Virginian. I have tried to avoid sensationalism, refraining from exploiting Jackson Hole's Hollywood history.

Primarily my criteria has been to bring together a group of essays by well-known Americans which not only tell us about the early Teton Country, but do so with class. In other words, hopefully what follows will give the reader an accurate idea of the highlights of the Teton Country history, but do so in such a fashion that says: "Read On!"

Within this book I have chosen some of the best examples of the descriptive, literary art. However, an exclusive diet of description could be tedious. Therefore, I have included essays outside of natural history. Jackson Hole and the town of Jackson have a colorful human history, and within this volume the reader will encounter a sampling of a unique people trying to find the correct balance between making a living and preserving a beautiful land. 